\title{
A Gathering of British Libraries
}

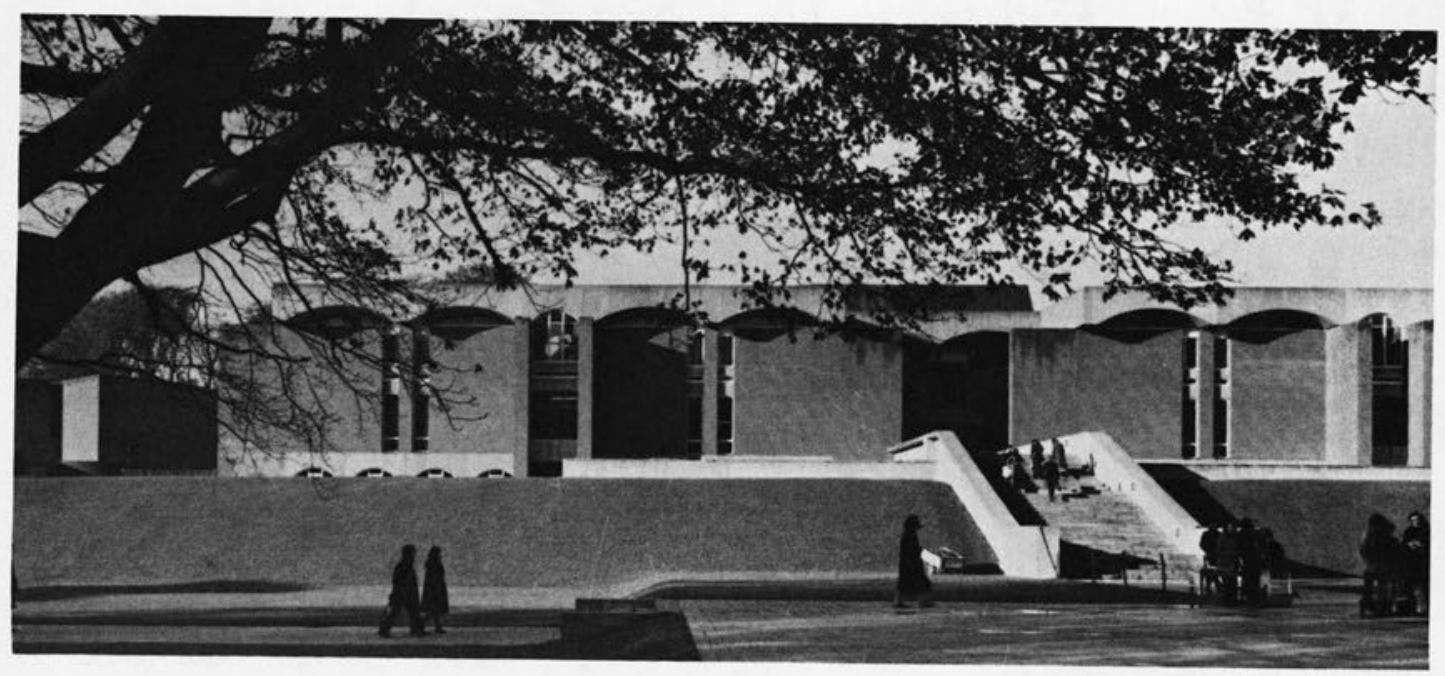

University of Sussex

The University of Sussex Library, Brighton. Designed by Sir Basil Spence, the building was completed in 1966, with an extension to the rear in 1971. It has a capacity for more than 500,000 volumes and 1,000 readers.

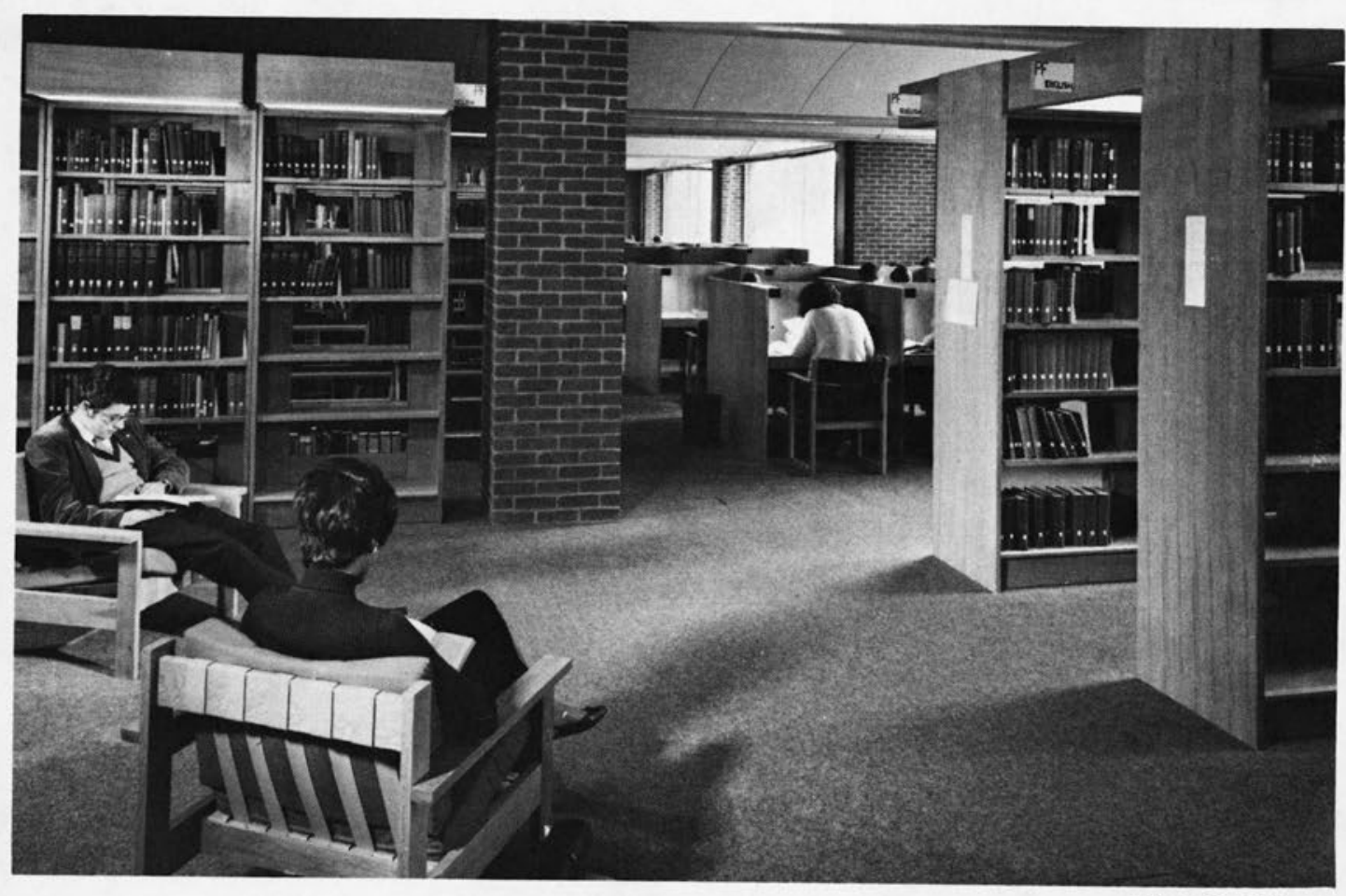

Reading and study areas, University of Sussex Library, Brighton. 


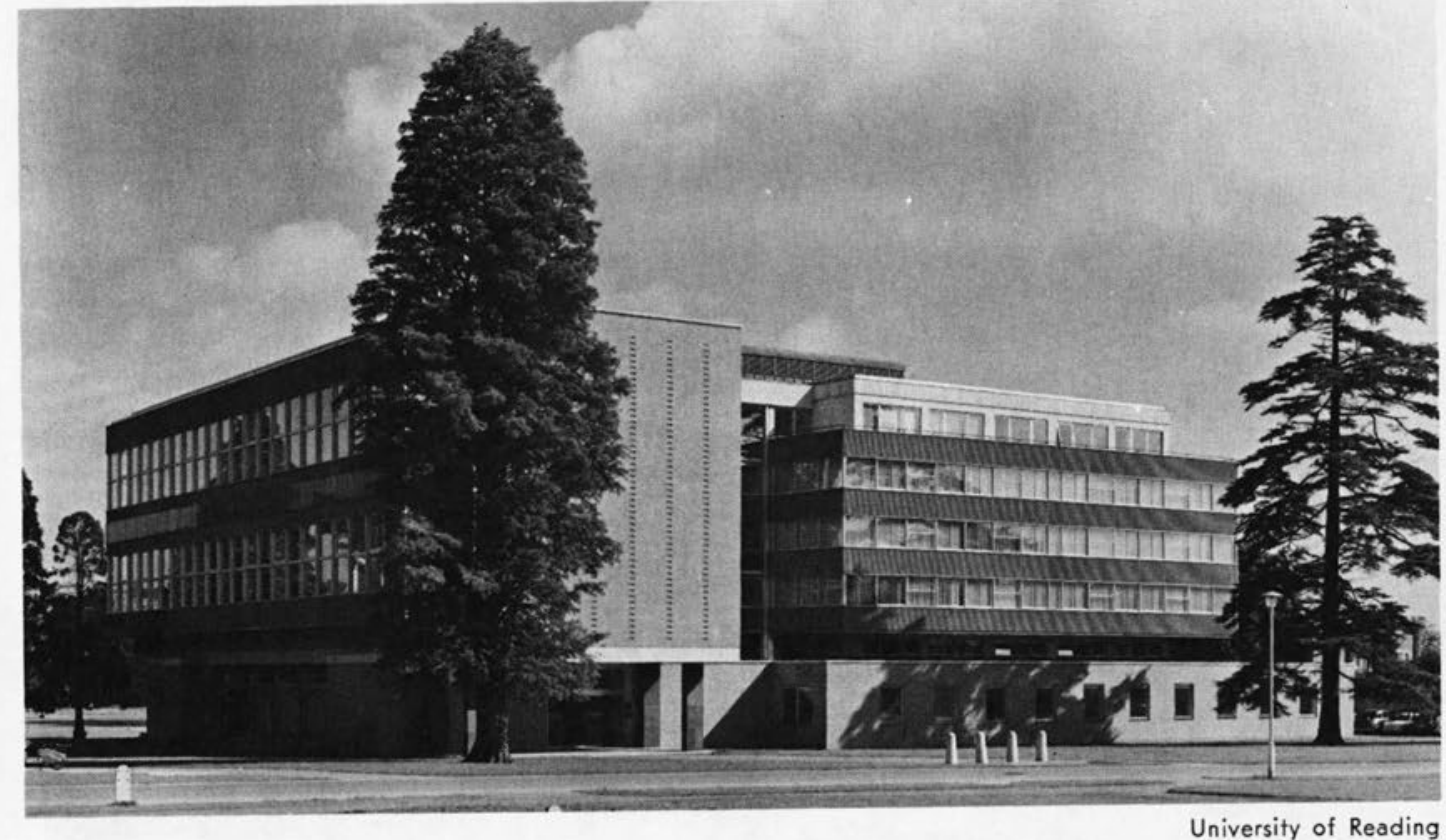

The Library, University of Reading. Completed in 1963, this building has a capacity for 500,000 volumes and 583 readers.
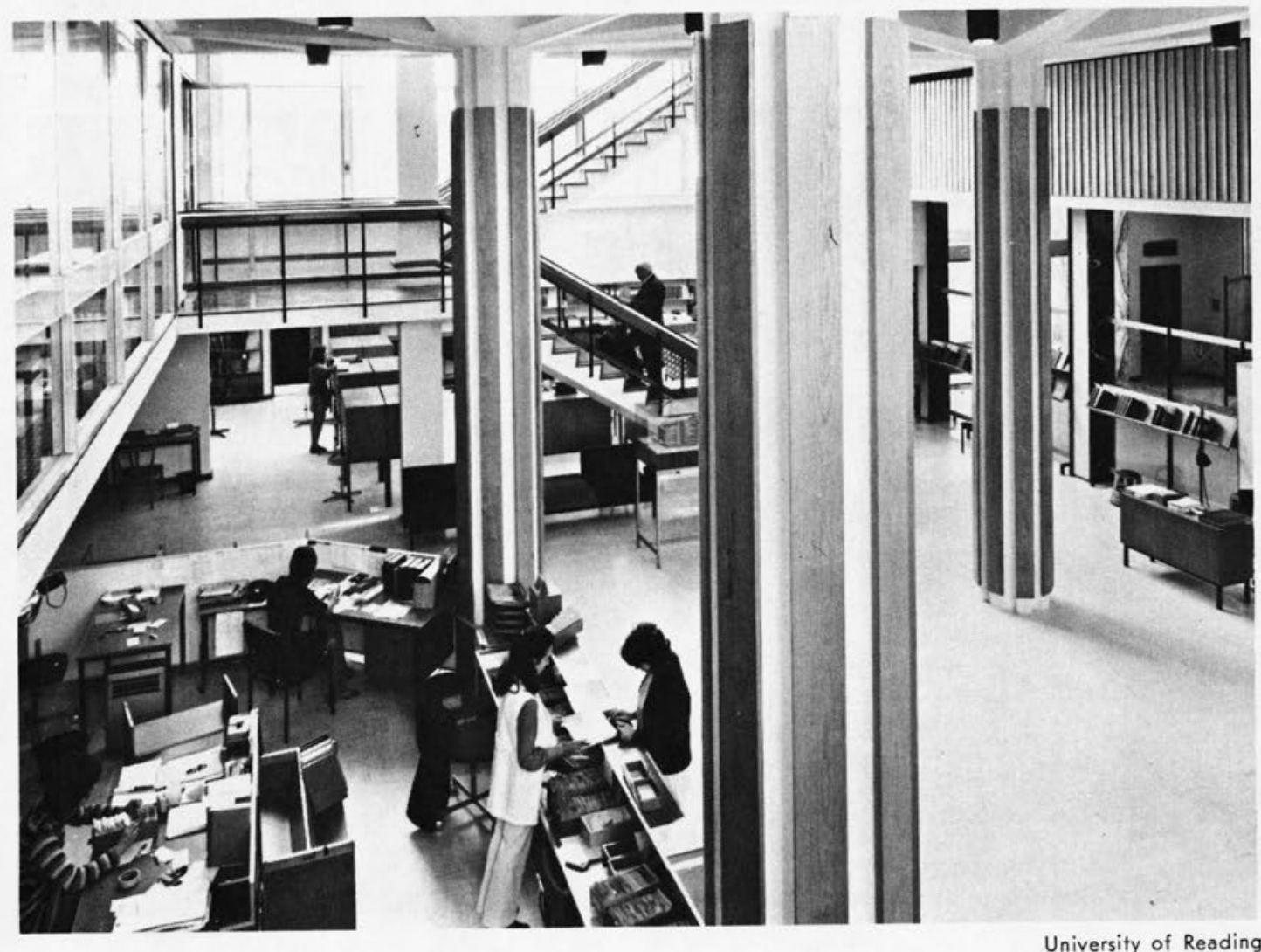

Ground floor, the Library, University of Reading. 


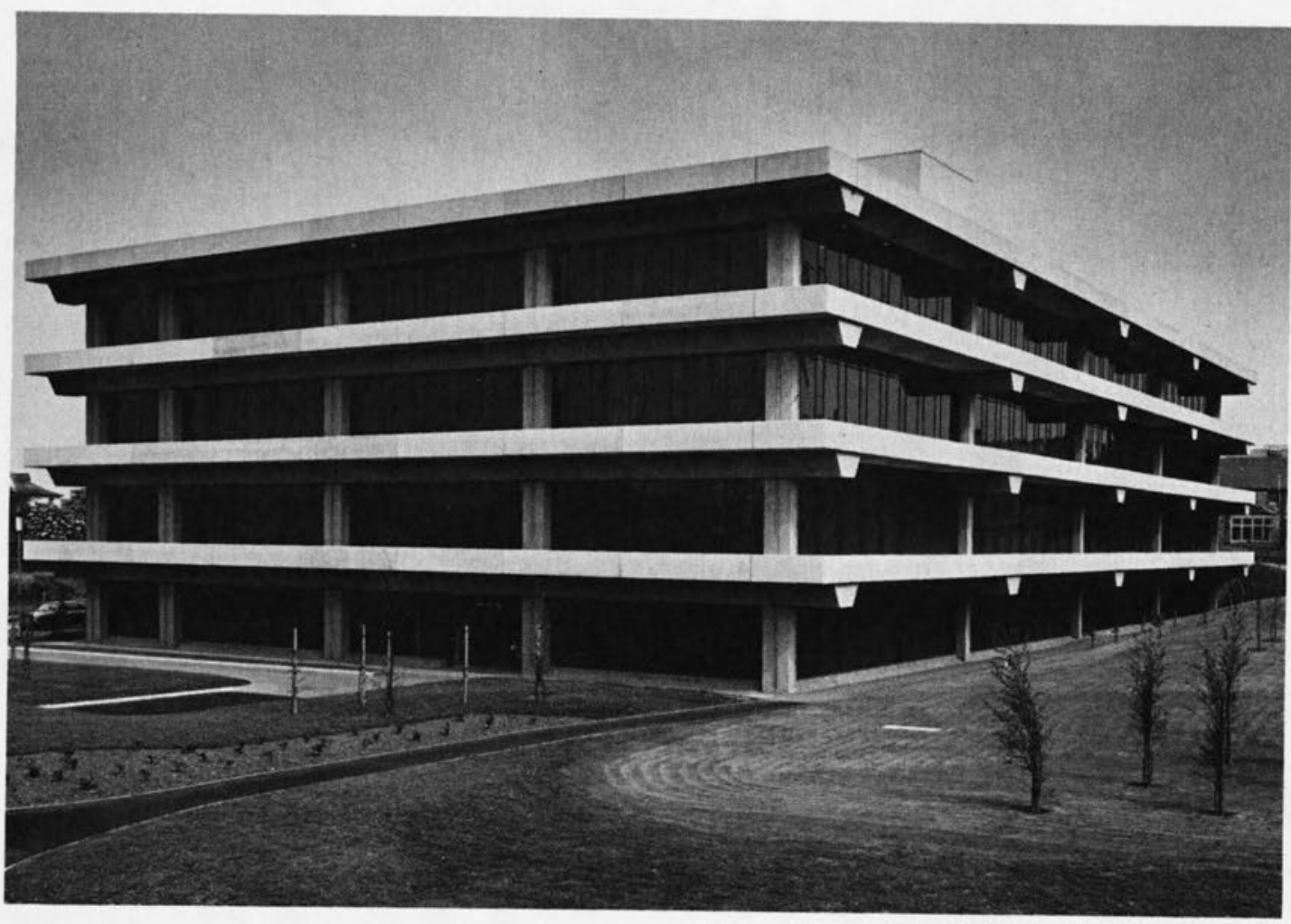

Library Photographic Unit, University College, Cardiff Arts and Social Studies Library, University College, Cardiff. Opened in 1975, the library has space for 445,000 volumes and 600 readers.

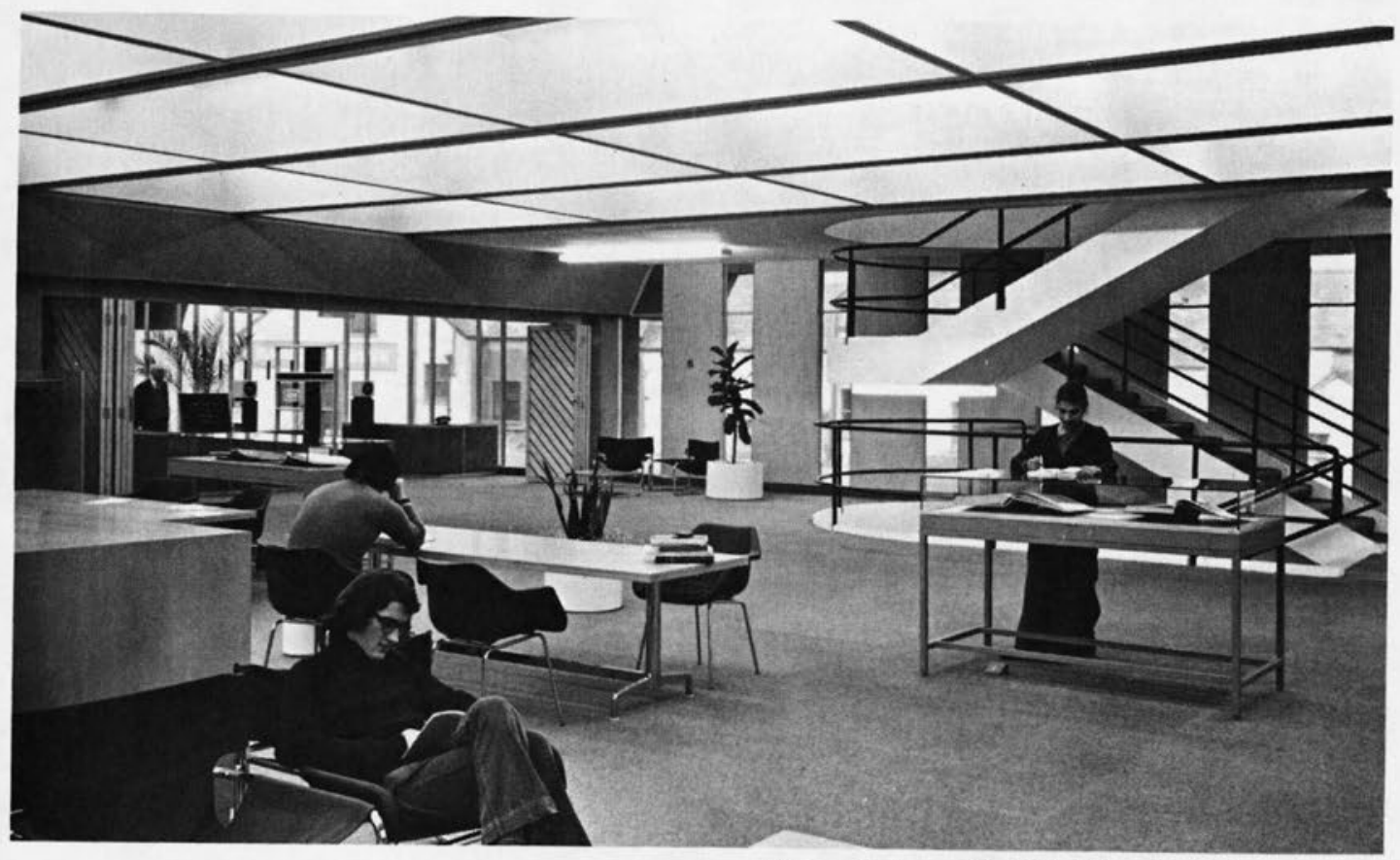

Library Photographic Unit, University College, Cardiff Entrance area, Arts and Social Studies Library, University College, Cardiff. 
490 / College \& Research Libraries • November 1977

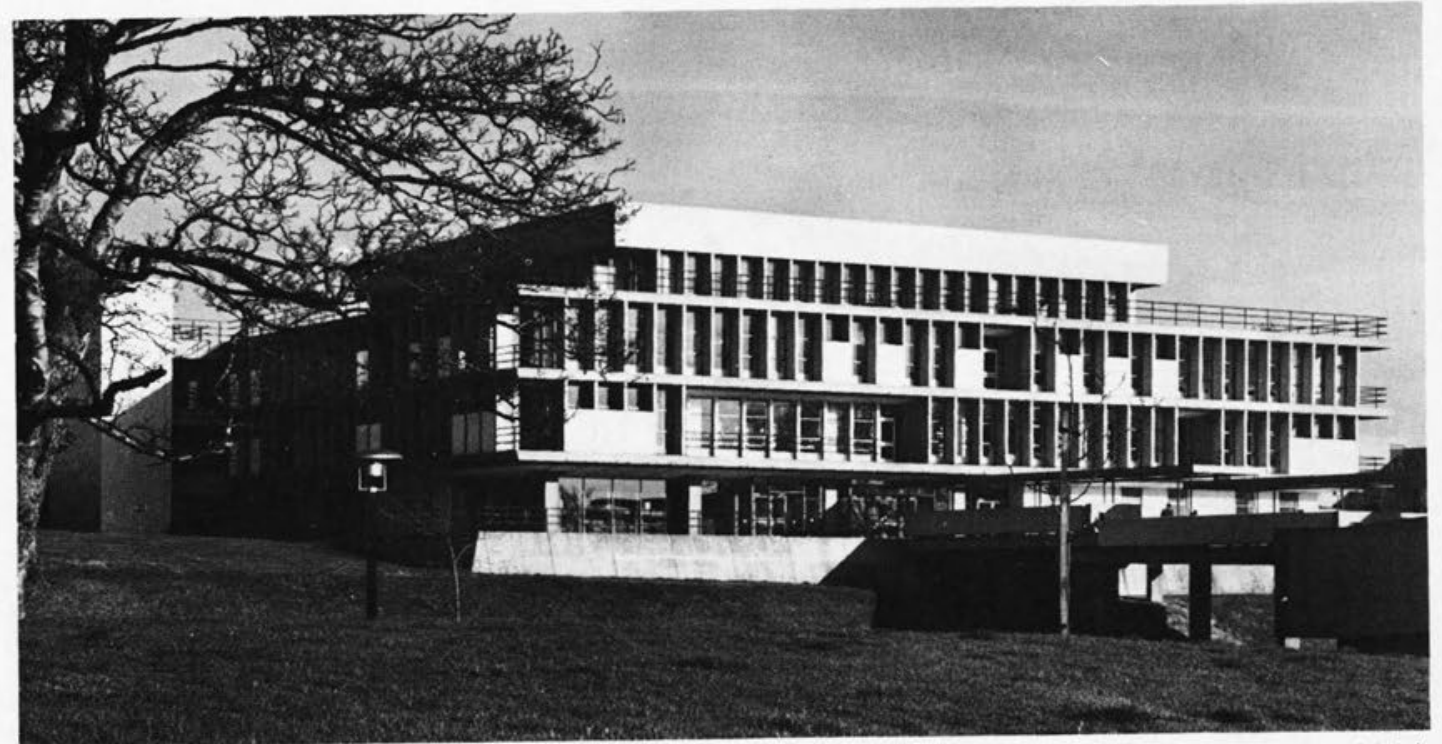

University of York

J. B. Morrell Library, University of York. Occupied in 1966, this building is the first stage of a multi-stage building and has a capacity for 250,000 volumes and 450 readers.

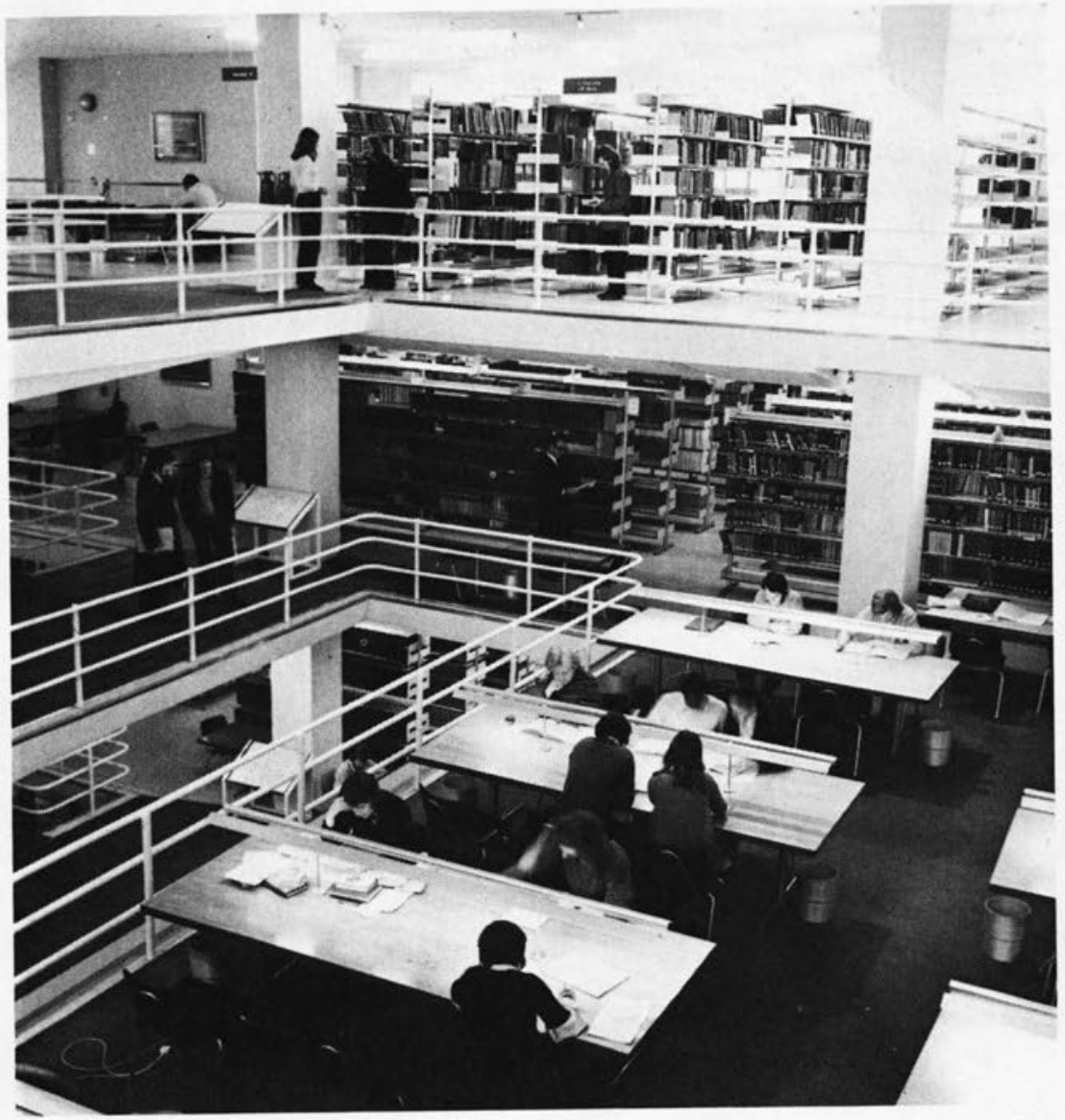

Stack and reading area, J. B. Morrell Library, University of York. 
Main Library, extension II, Swansea University College. View of south facade. This extension, completed in 1974, has stack area on two lower floors and reading rooms above.

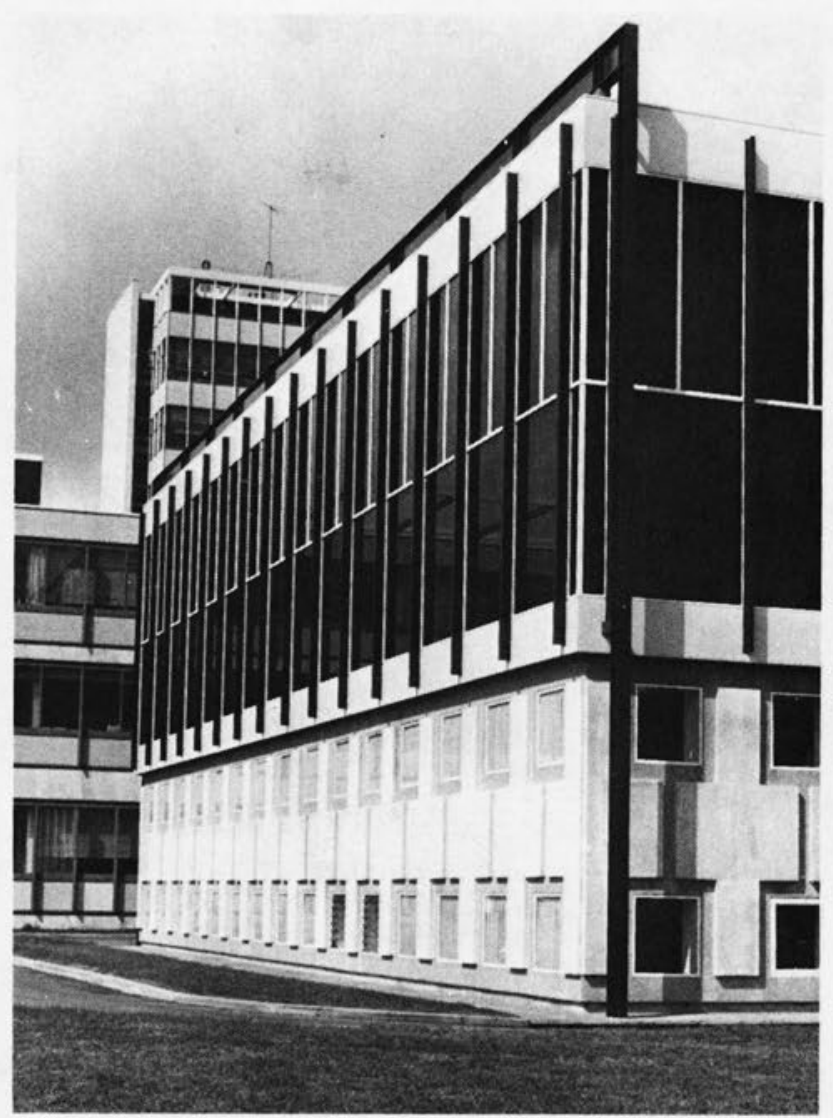

Swansea University College

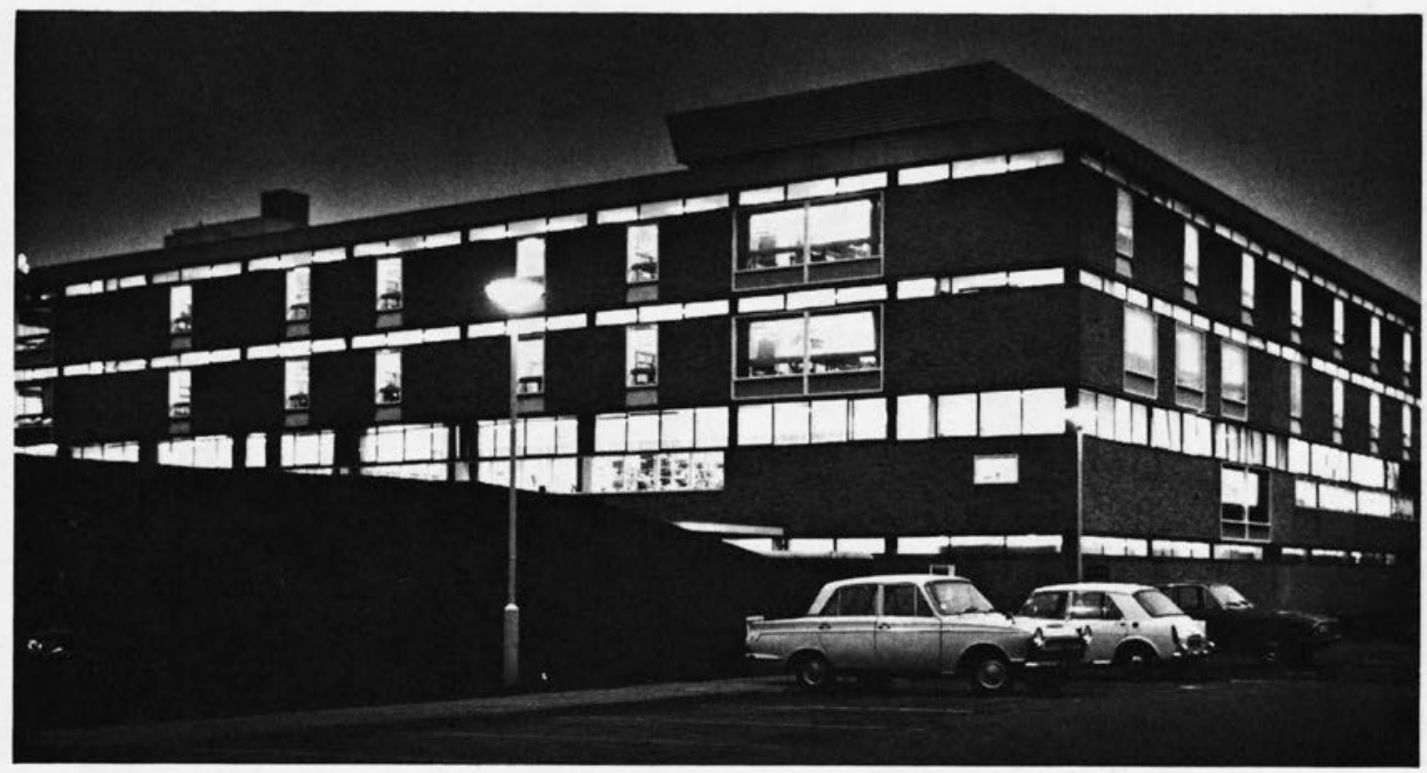

University of Lancaster

University of Lancaster Library. Completed in three stages-1966, 1968, and 1970-the library has seating for 1,000 readers and shelving for 450,000 volumes. 


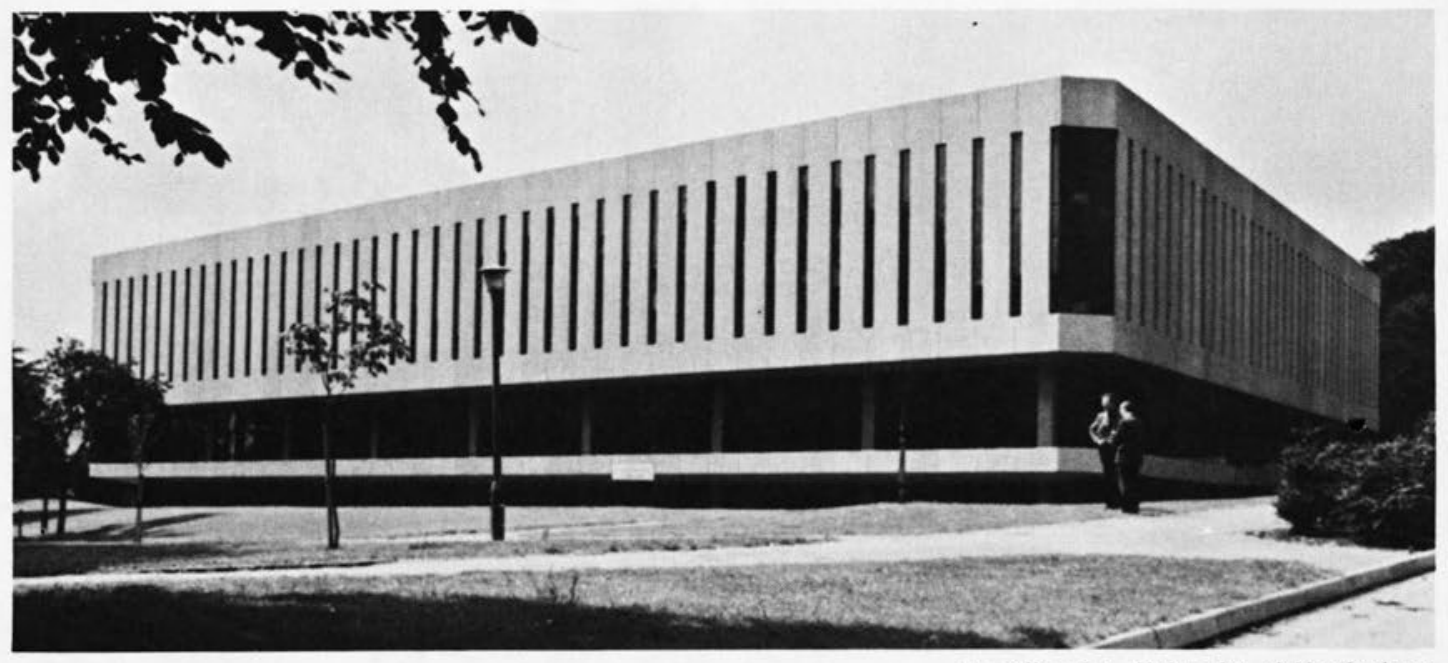

The Librarian, University of Nottingham

University Library, University of Nottingham. Opened in 1973, this building houses the collections in arts and social sciences as well as an extensive manuscripts department and a photographic unit.

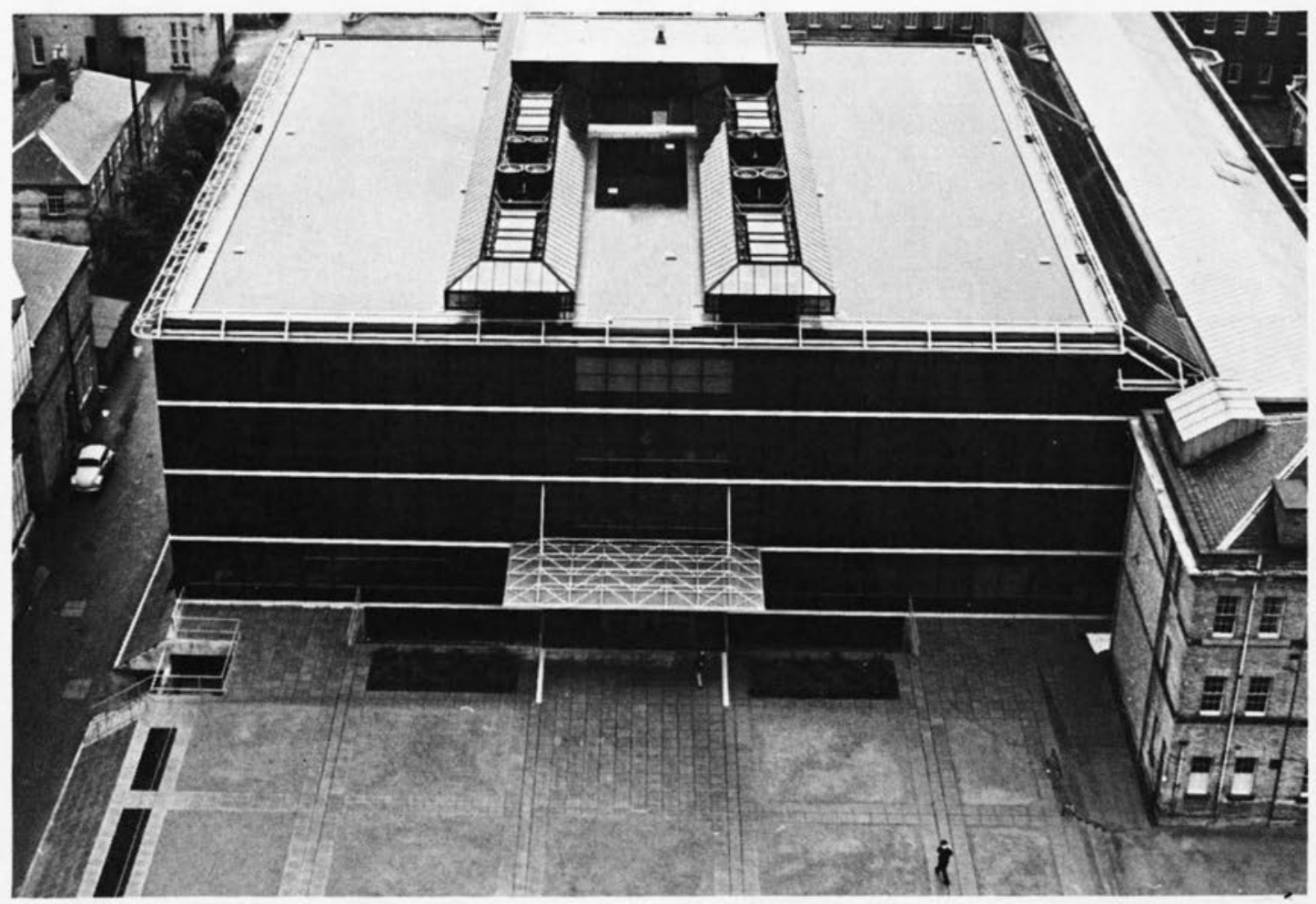

Central Photographic Unit, University of Leicester

University of Leicester Library. Completed in 1974, the library has seating for 800 readers and shelving for 500,000 volumes. As stated by the architect, Castle Park Dean Hook, "The building has been designed to give a high level of thermal capacity: to achieve this the external walls are dense concrete blockwork faced with solar heat reflecting glass, whilst the asphalt roof is kept covered with water." 


\section{British Libraries / 493}

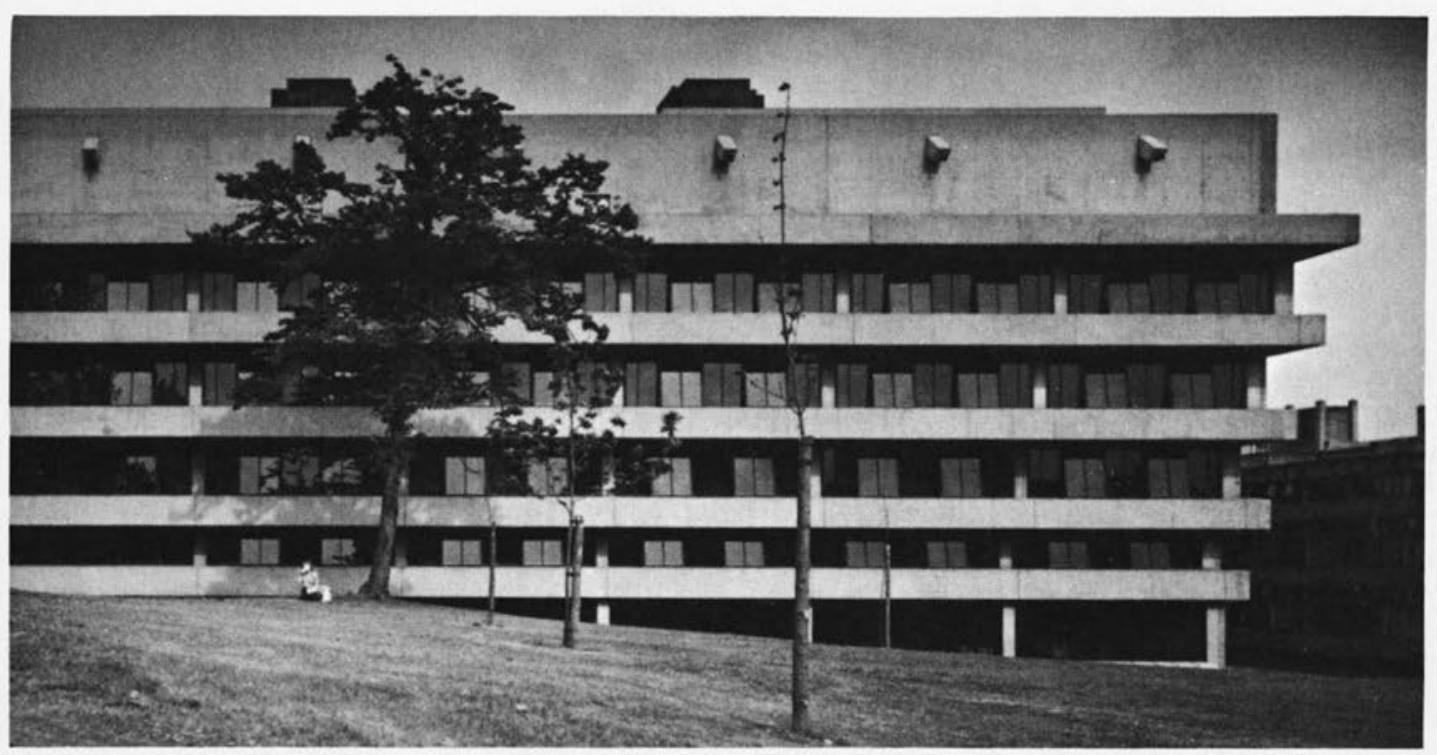

Brecht-Einzig Ltd.

South Library, University of Leeds. Opened in 1975, this building houses a working collection ("undergraduate library") and the main science and applied science collections. (The Brotherton Library, 1936, continues as the main arts and social science library.) Architects: Chamberlain Powell \& Bon.

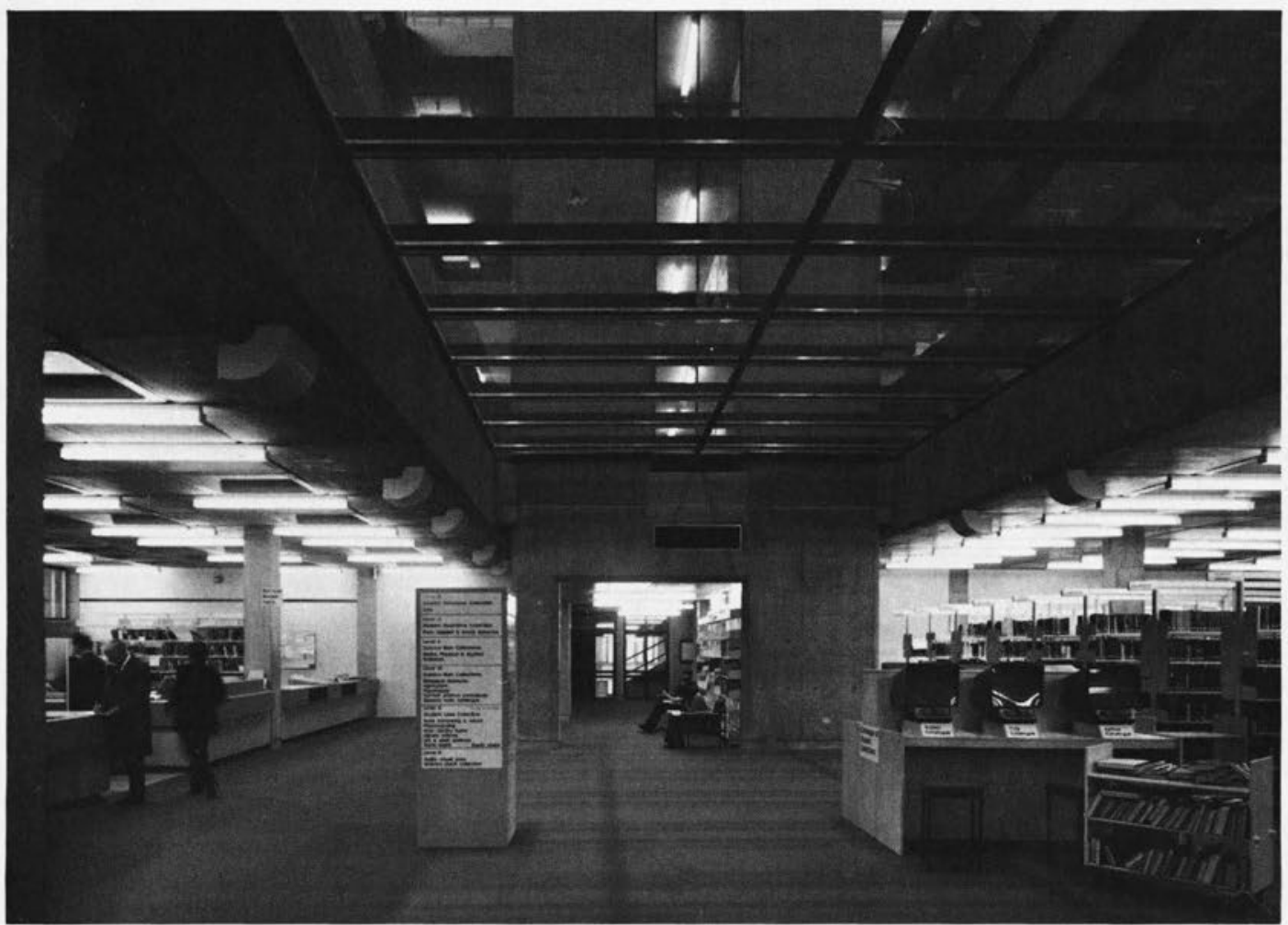

Brecht-Einzig Ltd.

Entrance floor, South Library, University of Leeds. 


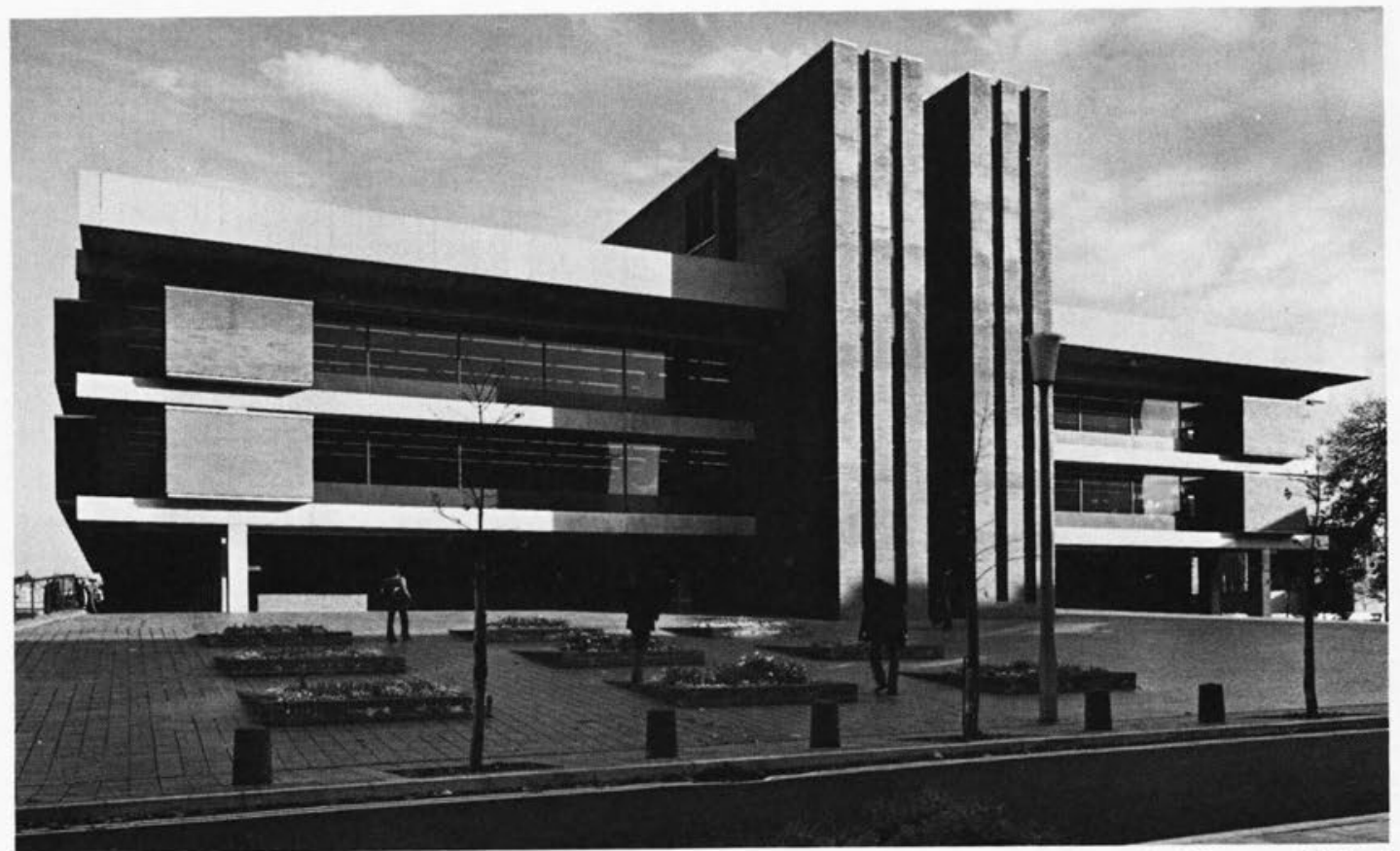

John Mills (Photography) Ltd.

Sydney Jones Library, University of Liverpool. Opened in 1976, this library serves the Faculties of Arts and of Social and Environmental Studies. This first stage has accommodation for 700,000 volumes and 670 readers. Architects: Sir Basil Spence, Glover \& Ferguson (Edinburgh).

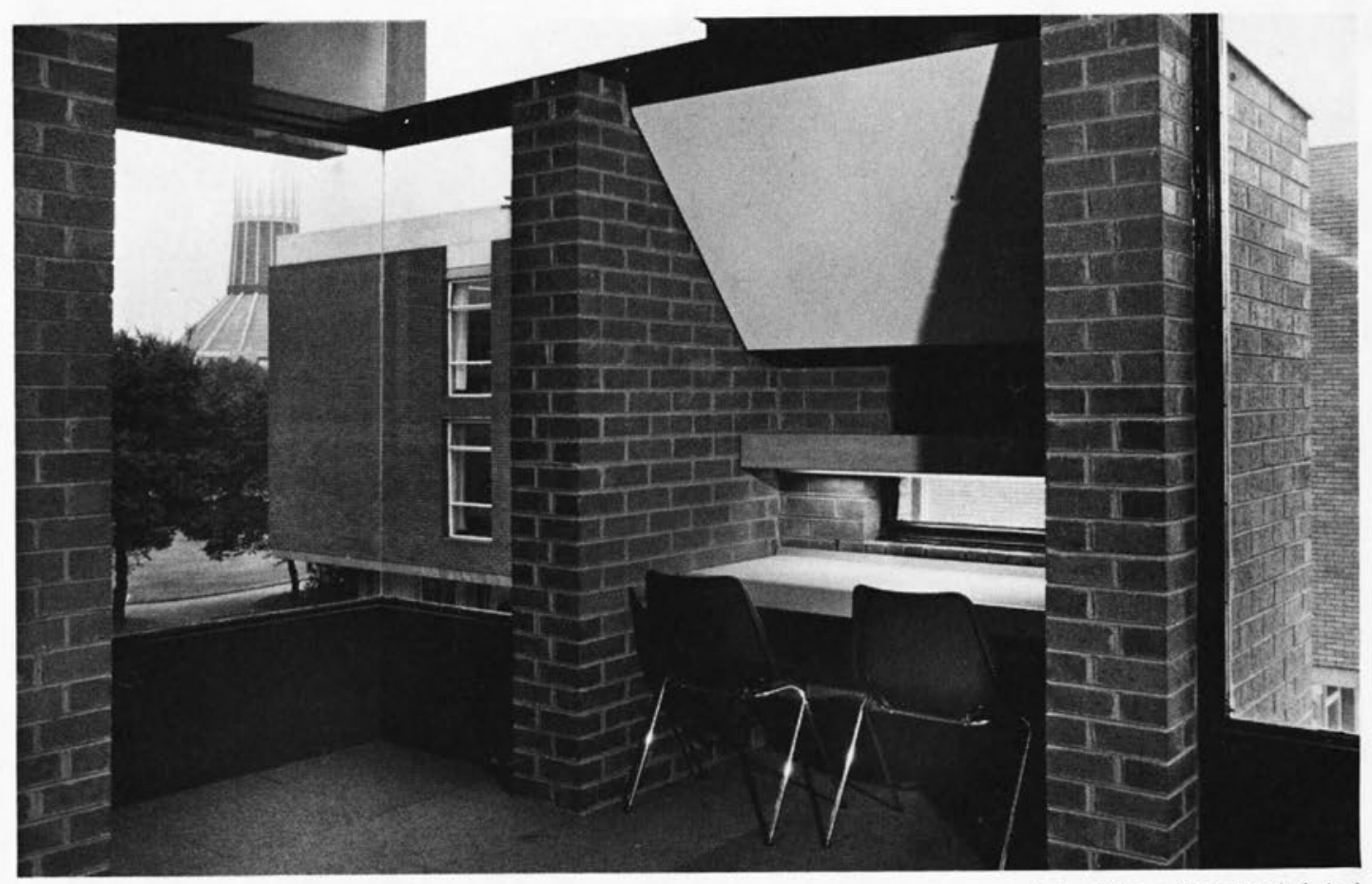

John Mills (Photography) Ltd.

Study carrel, Sydney Jones Library, University of Liverpool. 


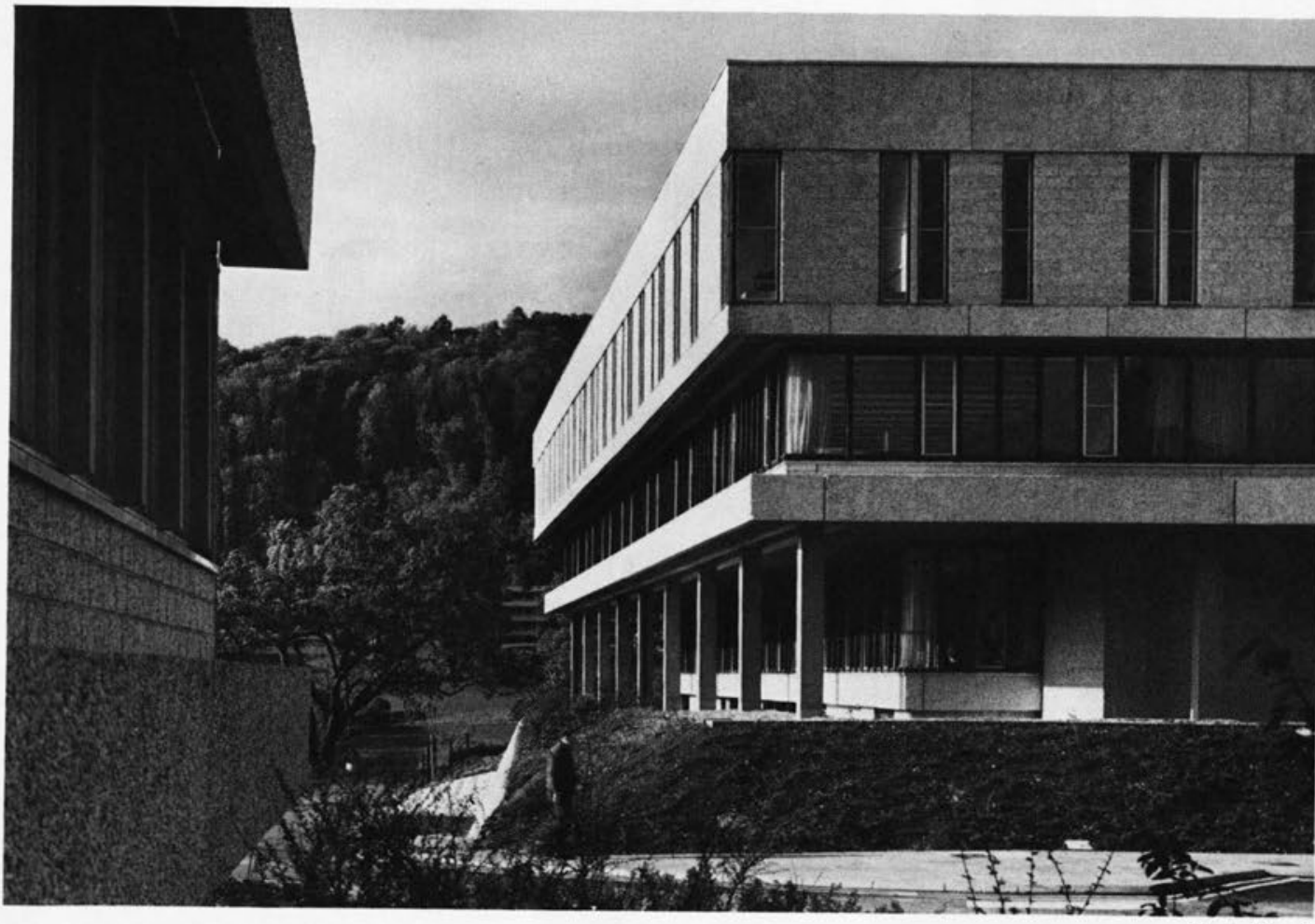

Henk Snoek

Library, University of Stirling. Completed in 1971, this four-story library has seating for 800 readers and 14,000 linear $m$. of shelving. Architects: Robert Matthew, Johnson-Marshall \& Partners.

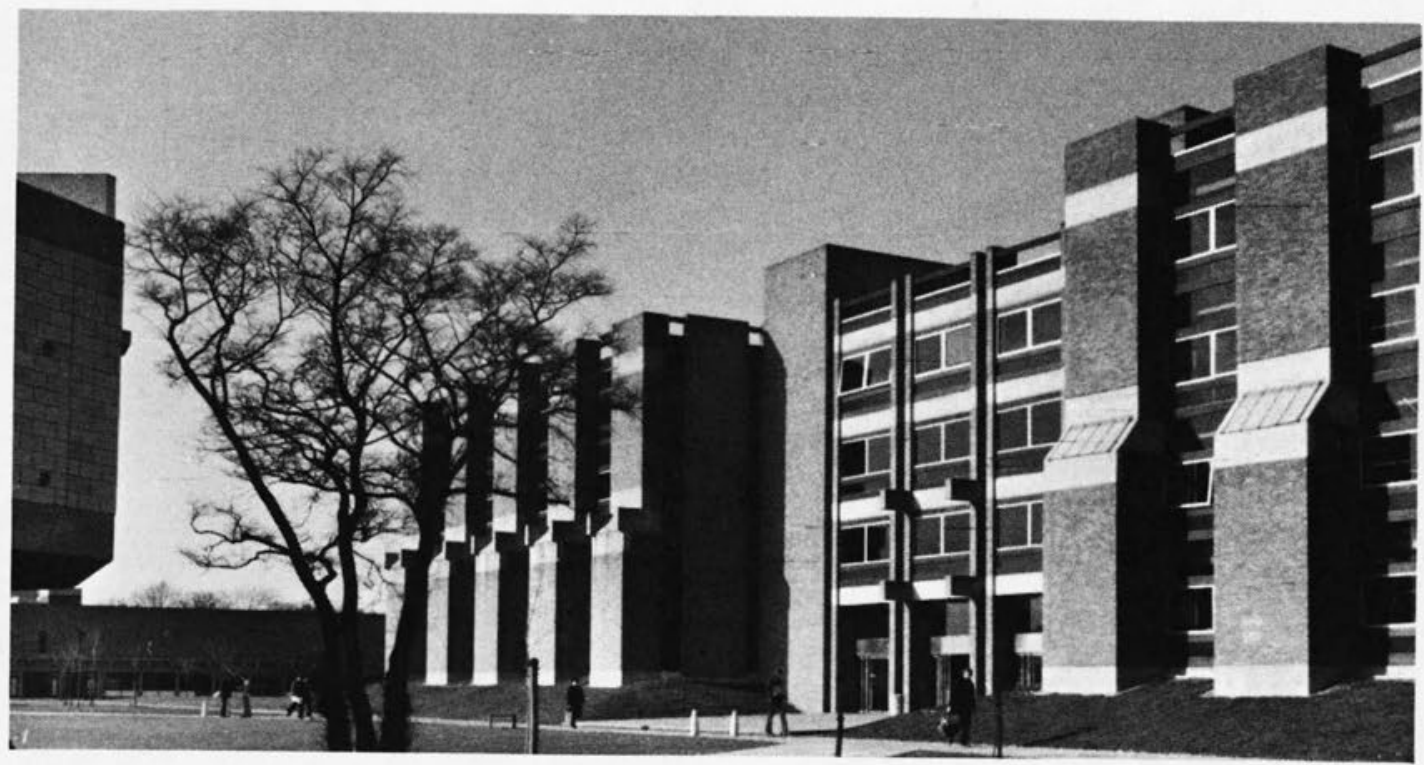

University of Kent at Canterbury

The University Library, University of Kent at Canterbury. Completed in 1973, the library was erected in two stages-the first by William Holford and Partners and the second by Farmer and Dark. 


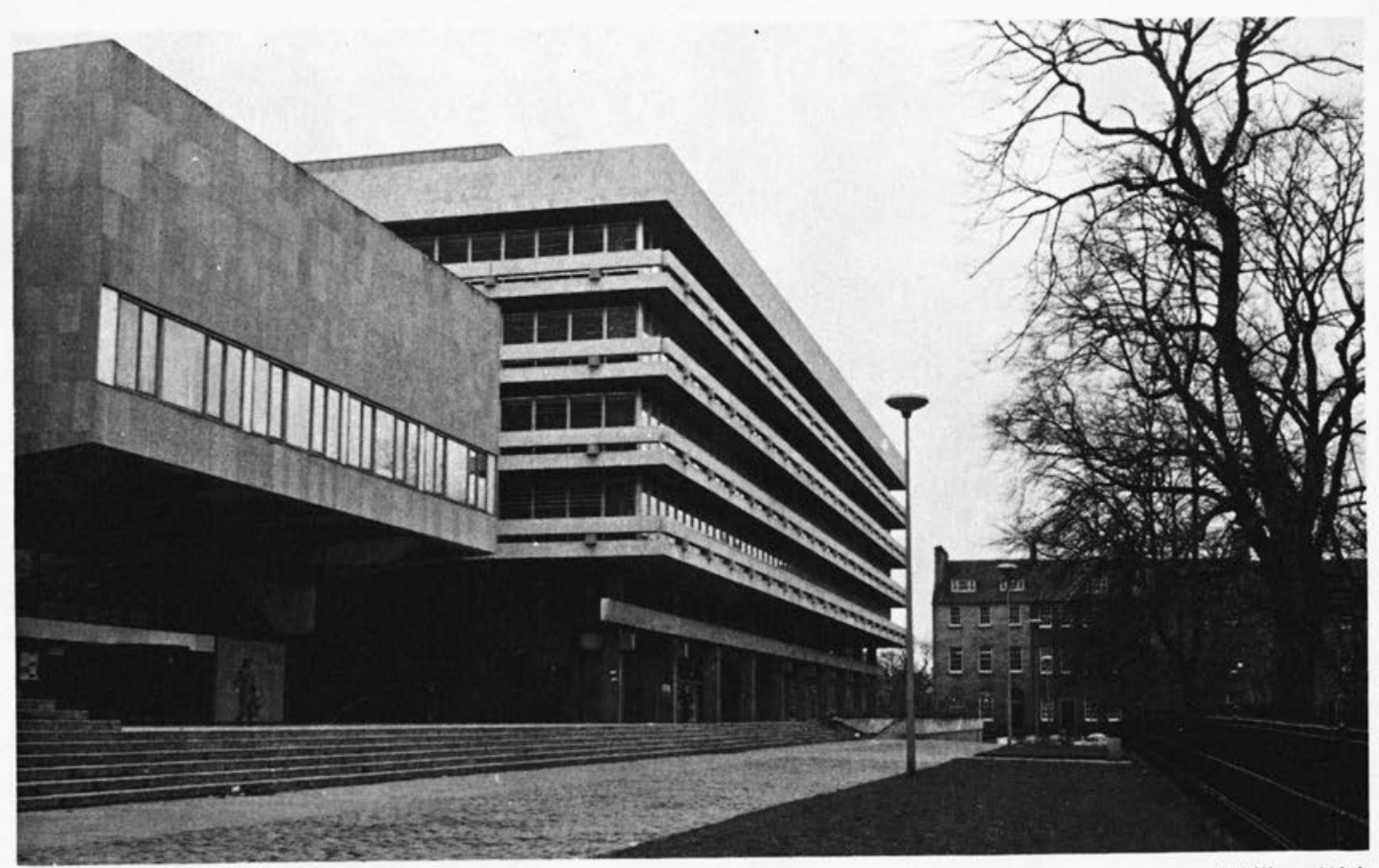

William Weir

Main Library, University of Edinburgh. View of north facade and entrance, George Square. This library, opened in 1967, was designed by Sir Basil Spence, Glover \& Ferguson (Edinburgh).

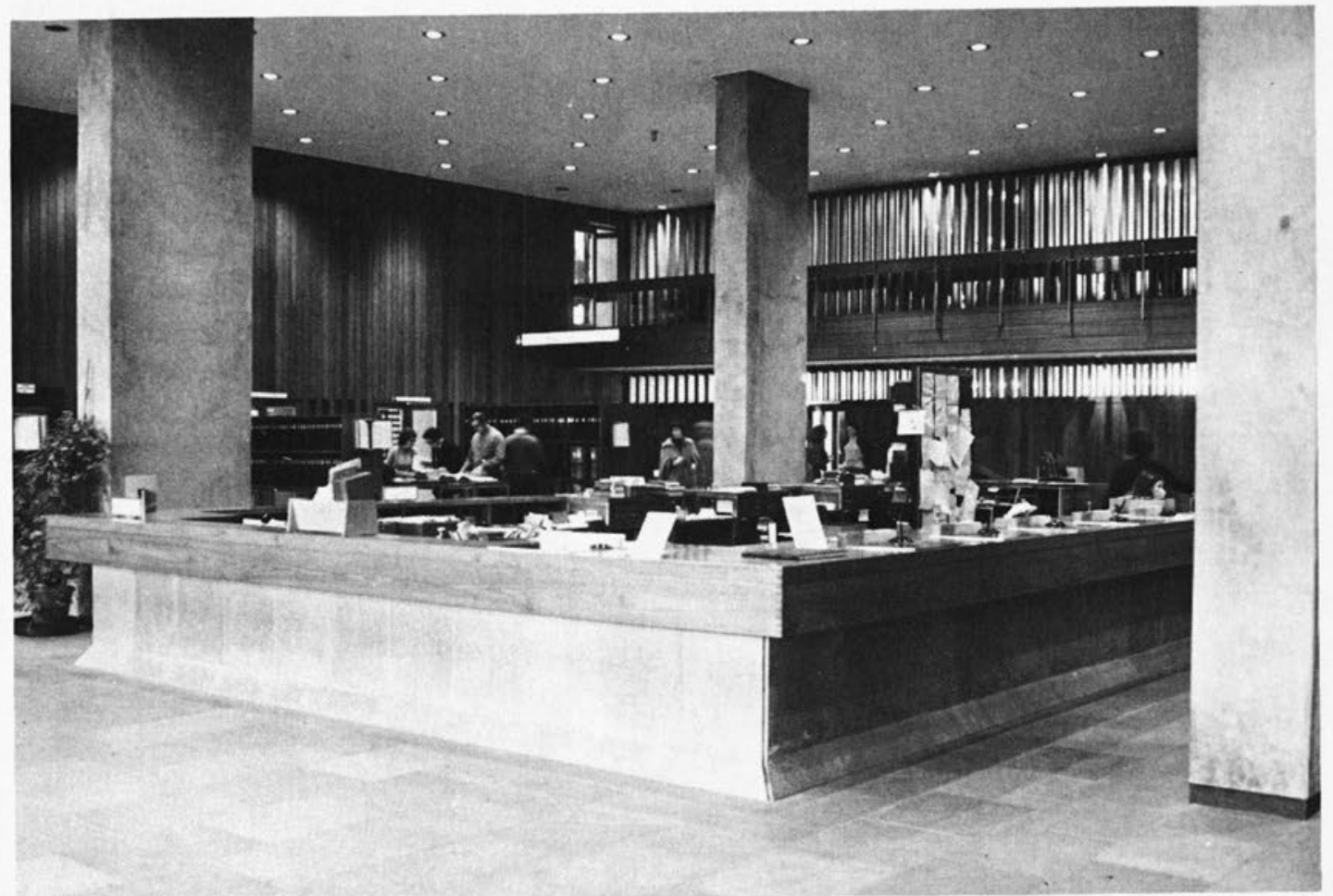

William Weir

Service desk, ground floor, Main Library, University of Edinburgh. 


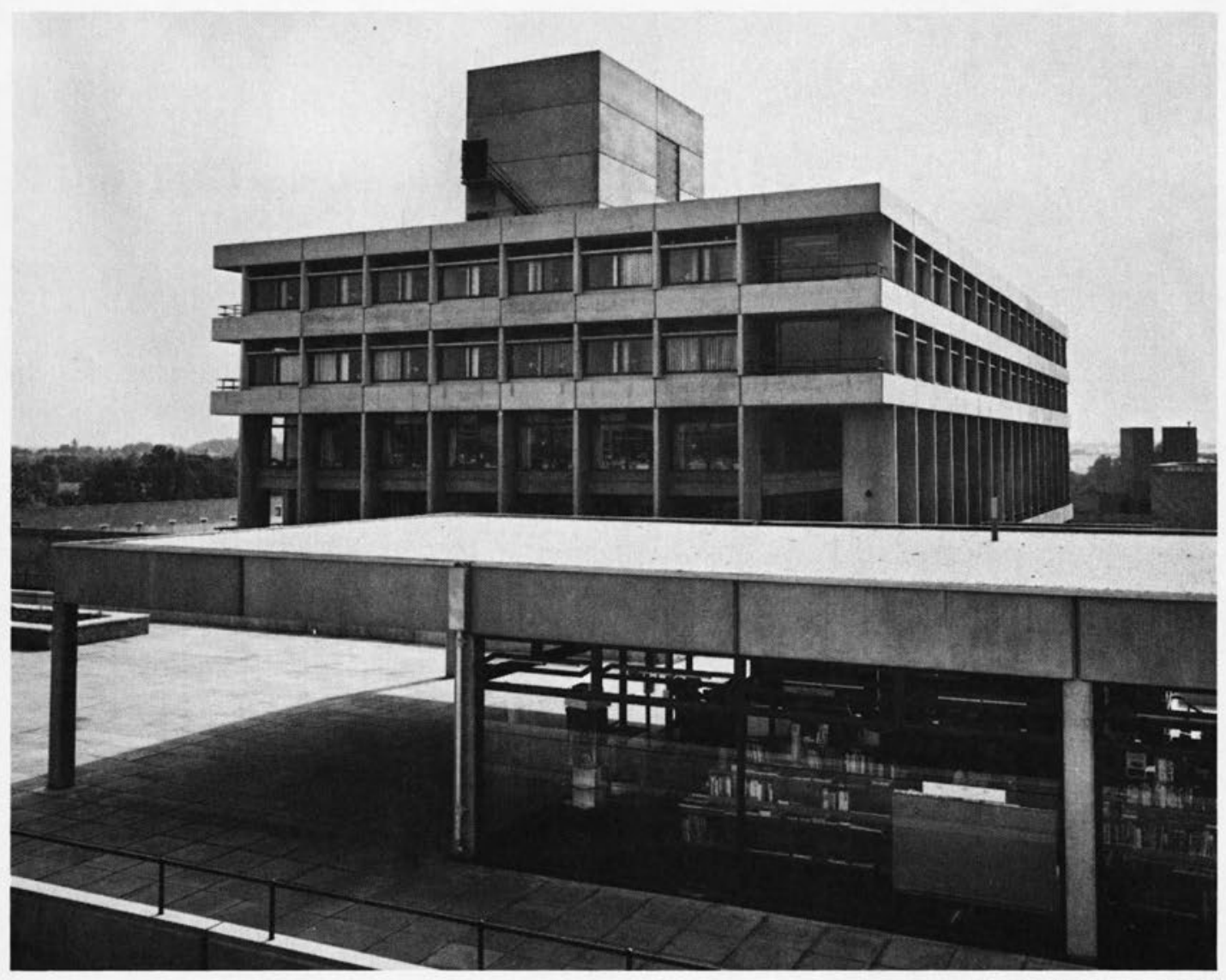

University of East Anglia

The Library, University of East Anglia, Norwich. Constructed in two stages (1968 and 1974), the library has space for 450,000 volumes and 1,300 readers. Access is at a middle level with two floors above and two below for collections and reading areas. Architects: Sir Denys Lasdun and Partners, Stage I; Feilden and Mawson, Stage II.

\section{ACKNOWLEDGMENTS}

For this photographic visit to British university libraries we are indebted to numerous institutions and their librarians as listed below:

University College, Cardiff: H. A. Cufflin, deputy librarian; University of East Anglia, Norwich: W. L. Guttsman, librarian; University of Edinburgh: P. B. Freshwater, deputy librarian; University of Kent at Canterbury: G. S. Darlow, librarian; University of Lancaster: A. Davies, librarian; University of Leeds: D. Cox, librarian; University of Leicester: Douglas G. F. Walker, librarian; University of Liverpool: V. E. Knight, university librarian; University of Nottingham: R. S. Smith, librarian; University of Reading: James Thompson, librarian; University of Stirling: P. G. Peacock, librarian; University of Sussex: P. R. Lewis, librarian; University College of Swansea: D. M. Ellis, deputy librarian; and University of York: Harry Fairhurst, librarian. 